\title{
Aa $\mathrm{Vv}$. , Histoire, vues littéraires
}

\section{Maria Chiara Gnocchi}

\section{(2) OpenEdition}

\section{Journals}

\section{Édition électronique}

URL : https://journals.openedition.org/studifrancesi/26901

DOI : 10.4000/studifrancesi.26901

ISSN : 2427-5856

\section{Éditeur}

Rosenberg \& Sellier

\section{Édition imprimée}

Date de publication : 1 avril 2007

Pagination : 218

ISSN : 0039-2944

\section{Référence électronique}

Maria Chiara Gnocchi, « Aa Vv., Histoire, vues littéraires », Studi Francesi [En ligne], 151 (LI | I) | 2007, mis en ligne le 30 novembre 2015, consulté le 23 novembre 2021. URL : http://journals.openedition.org/ studifrancesi/26901 ; DOI : https://doi.org/10.4000/studifrancesi.26901

\section{Ce document a été généré automatiquement le 23 novembre 2021.}

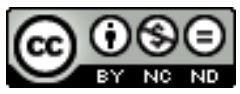

Studi Francesi è distribuita con Licenza Creative Commons Attribuzione - Non commerciale - Non opere derivate 4.0 Internazionale. 


\title{
Aa Vv., Histoire, vues littéraires
}

\author{
Maria Chiara Gnocchi
}

\section{RÉFÉRENCE}

“Notre librairie”, n. 161, Histoire, vues littéraires, mars-mai 2006, pp. 157.

1 «En Afrique, il n'y a pas d'histoire», disait le philosophe Hegel. S'efforçant de contrer cette idée, qui implique la désignation des peuples africains par défaut, sous le signe de l'absence d'histoire et d'historicité, divers intellectuels d'origines africaines, caribéennes et des Mascareignes ont construit «des pratiques scripturales qui s'exercent comme stratégies de détournement, d'interrogation des lacunes de l'histoire officielle» (éditorial par Véronique Bonnet). Ce numéro de «Notre librairie» contribue à approfondir la réflexion sur les relations entre littérature, histoire et critique littéraire, en relation à ces pays du Sud du monde.

2 Anthony Mangeon, auteur du premier article, avance une réflexion très intéressante sur la concomitance de l'émergence de deux ambitions «universalistes» dans l'Europe de la fin du XVIII ${ }^{\mathrm{e}}$ siècle: naissent en effet, à cette époque-là, à la fois la philosophie de l'histoire et les premiers projets de colonisation de l'Afrique. Au XIX ${ }^{\mathrm{e}}$ siècle, la première se met au service des seconds, et alimente l'idéologie impérialiste; au siècle suivant, l'une est discréditée, les autres voient leur fin. «Dans ce compagnonnage, nulle dialectique cependant, mais une série de tensions constantes», précise l'auteur (Romans d'Afrique, philosophies de l'histoire, p. 8). D'autant plus intéressants se révèlent, dans cette optique, les réflexions sur l'histoire, son écriture et sa philosophie qui se développent dans les romans africains, dont Mangeon présente quelques exemples.

Dans une étude sur La mémoire des traites et de l'esclavage au regard des littératures africaines, Kangni Alem met en évidence le fait que des sujets aussi cruciaux et problématiques que l'esclavage et la traite, sources importantes d'inspiration pour les littératures nord-américaine et caribéenne, semblent être quasiment absents dans les romans et récits produits en Afrique - ce qui, suggère l'auteur, «donne la mesure de la gravité du tabou et de sa banalisation par omission»(p. 24). À signaler, enfin, un 
entretien avec Édouard Glissant réalisé par Alessandro Corio et Francesca Torchi. L'écrivain et philosophe martiniquais met l'accent sur l'implication profonde de l'écriture dans l'analyse de notre histoire immédiate. "Véritable "tête chercheuse", l'acte d'écriture permet en effet d'interroger l'histoire et de concevoir les évolutions du monde contemporain» (Une autre manière de lire le monde, p. 112). 